\title{
Gains from trade and environmental policy under imperfect competition and pollution from transport
}

Citation for published version (APA):

Soete, L. L. G., \& Ziesemer, T. H. W. (1997). Gains from trade and environmental policy under imperfect competition and pollution from transport. MERIT, Maastricht Economic Research Institute on Innovation and Technology. MERIT Research Memoranda No. 003 https://doi.org/10.26481/umamer.1997003

Document status and date:

Published: 01/01/1997

DOI:

10.26481/umamer.1997003

Document Version:

Publisher's PDF, also known as Version of record

\section{Please check the document version of this publication:}

- A submitted manuscript is the version of the article upon submission and before peer-review. There can be important differences between the submitted version and the official published version of record.

People interested in the research are advised to contact the author for the final version of the publication, or visit the DOI to the publisher's website.

- The final author version and the galley proof are versions of the publication after peer review.

- The final published version features the final layout of the paper including the volume, issue and page numbers.

Link to publication

\footnotetext{
General rights rights.

- You may freely distribute the URL identifying the publication in the public portal. please follow below link for the End User Agreement:

www.umlib.nl/taverne-license

Take down policy

If you believe that this document breaches copyright please contact us at:

repository@maastrichtuniversity.nl

providing details and we will investigate your claim.
}

Copyright and moral rights for the publications made accessible in the public portal are retained by the authors and/or other copyright owners and it is a condition of accessing publications that users recognise and abide by the legal requirements associated with these

- Users may download and print one copy of any publication from the public portal for the purpose of private study or research.

- You may not further distribute the material or use it for any profit-making activity or commercial gain

If the publication is distributed under the terms of Article $25 \mathrm{fa}$ of the Dutch Copyright Act, indicated by the "Taverne" license above, 


\title{
Gains from Trade and Environmental Policy under Imperfect Competition and Pollution from Transport ${ }^{1}$
}

\author{
Luc Soete and Thomas Ziesemer
}

\section{Introduction}

The relationship between the environment and international trade has been investigated in the framework of several international trade models that have been extended to contain the factor environmental pollution. The Ricardian trade model has been used by Pethig (1976) and the Heckscher-Ohlin model has been used in different ways by Pethig (1976), McGuire (1982) and Merrifield (1988). Conrad (1993) applied the Cournot-Brander-Spencer model and Markusen, Morey and Olewiler (1993) have applied the Horstmann-Markusen model. In this paper we apply the Chamberlin-Krugman model.

We analyze the environmental transport costs of international trade and illustrate how they reduce the conventional gains from trade if their is no environmental policy reducing pollution in the trading countries. The motivation stems from the fact that in economic theory pollution is assumed to come from production, consumption or the use of capital. However, it is commonly pointed out in the business press that one of the largest users of energy is transport, which is using roughly one third of energy in the OECD as industry and residential/commercial does. However, the share of transport is increasing, whereas that of the other two users is decreasing. On average, international transportation requires larger travel distances than national transportation. International trade therefore inevitably contributes to pollution because it increases energy use. Pollution from transport, however, has not been analyzed in the literature on international trade and the environment.

Moreover, we analyze the effects of technical progress and environmental taxes on prices of goods and pollution. We do so from the point of view of a market approach to

\footnotetext{
${ }^{1}$ This paper is a revised version of MERIT Research Memorandum 92-022, September 1992. It has been discussed at the Free University of Berlin, the 'Jahrestagung des Vereins für Socialpolitik' in Münster 1993 and at the conference from which the current volume has originated. We are grateful for all comments received by the audience of these presentations and especially to Theon van Dijk, Karin Kamp and Rene Kemp.
} 
internalization and from the point of view of optimal taxation.

To demonstrate the basic line of thought we add transport costs and pollution $\left(\mathrm{CO}_{1,2}\right.$, $\mathrm{SO}_{2}$, smoke, $\mathrm{NO}_{\mathrm{x}}$ ) to a model of monopolistic competition and increasing returns first developed by Krugman (1979). In this model, the gains from trade consist in the first instance of the higher diversity of consumption goods supplied and the greater use of increasing returns to production. By adding transport costs as man-hours needed for national and international distances rather than iceberg cost as in Krugman (1983), we can analyze within a comparative static framework several forms of technical progress in the transport sector. Furthermore, we make pollution depend explicitly on transport rather than on production. Dogs, Ellwanger and Platz (1991) estimate the external costs of lorries to be $1 / 6$ of transport revenues. In the model developed below transporters will have to pay for pollution rights bought from households or will have to pay taxes which are paid to households.

In the literature the result that conventional gains from trade may be outweighed by losses from increased pollution has been illustrated in perfectly competitive models by Pethig (1976) and Siebert (1977) with pollution directly related to output production. We re-establish these results in an imperfectly competitive model with pollution related to transport. One reason for doing so is closely related to the fact that specialisation and mobility of goods and activities are generally considered costless both in trade and growth models. Specialisation, whether within the national boundaries of a country or at the broader international level, is of course at the core of growth primarily because of the improved allocation of resources and the reaping of advantages associated with increasing returns to scale. It is precisely this latter feature which has been brought to the forefront in both "new" trade theory (Krugman, 1981) and "new" growth theory (Judd, 1985). However, the reaping of such scale advantages that might also involve scale advantages in reducing emissions in production, ignores the impact of increased transport flows, and in particular the impact on pollution from such increased flows.

The use of a monopolistic framework rather than a perfectly competitive one on the other hand, means that "Pigovian policy" will generally not be optimal. As Buchanan (1969) and many others after him have pointed out, such a policy may increase the inefficiencies from monopolistic behaviour. Second-best optimum policy results have been derived within a partial equilibrium setting by Lee (1975), Barnett (1980) and Conrad (1993). In this paper, we provide a general equilibrium comparison of equilibrium and optimal policies under 
monopolistic conditions.

A second difference from first-best models is the existence in imperfectly competitive models of an endogenous number of firms. Until now only Markusen, Morey and Olewiler (1993) discussed the effects of environmental policy on the number of non-competitive firms, applying the Horstmann-Markusen model. They do so under the rather restrictive assumption that fixed costs are very high relative to demand so that at most there are three firms producing in the economy. The welfare effect of closing one firm may then be, not surprisingly, large. We discuss the situation of many firms where the closing of one is a marginal event. In other words, we take an intermediate position between that of Markusen, Morey and Olewiler (1993) and the perfectly competitive one.

In comparison with the other imperfect competition models, the Krugman model has some interesting empirical features which make it more relevant than the other models. Firstly, it considers differentiated goods, a property that it shares with the model by Markusen, Morey and Olewiler, whereas other models consider homogeneous goods, which is much less realistic. Secondly, the Krugman model has zero profits which is much more realistic than positive profits because profits tend to vanish at the two-digit level (see Morisson 1989, for the US, Canada and Japan and Katz and Summers 1989, for US data and Maks 1994, for data for the Netherlands) and therefore may be occasionally relevant, of course, on the firm level but less so for general equilibrium considerations. This also casts some doubts on the relevance of profit shifting models simply because profits are largely absent. Thirdly, models mentioned above have linear demand curves whereas the empirical estimates of demand functions show that log-linear specifications are the best; they imply constant elasticity demand functions as does the love-of-variety utility function of the Krugman model.

Finally, a crucial feature of the Krugman model is the symmetry assumption of having two identical countries. In our case this implies that both countries have the same policy. Therefore there can be no terms of trade effects as in Siebert (1979) and Krutilla (1991). The symmetry assumption and the endogenous number of firms seems to be a realistic way to capture the EU attitude of the EU to not take the initiative in $\mathrm{CO}_{2}$ policy because of possible negative effects on international competitiveness. One way of interpreting the model is that the EU and the rest of the world are assumed to have successfully negotiated to undertake identical policies. The model then reflects the effects of policy on international 
competitiveness.

The structure of the paper is as follows. In section 2 we extend the Krugman model to include a transport sector, pollution and pollution payments. Section 3 contains the decision of the household and those of producers and transporters. In section 4 the model is solved for exogenous taxes on or prices for pollution rights. This solution is compared to that of autarky in section 5. The gains from trade result is derived in section 6 . The equilibrium solution for the existence of markets for pollution rights is presented in section 7 and the solution for optimal taxes in section 8. Section 9 summarizes and concludes.

\section{The model}

We consider an economy that has two types of resources: labour $\mathrm{L}$ and the environment $\mathrm{E}$. Households appreciate consumption $\mathrm{c}_{\mathrm{i}}$ of $\mathrm{n}$ varieties produced at home and $\tilde{c}_{j}$ of $\mathrm{n}^{*}$ varieties imported and are assumed to have - for the mere sake of simplicity - additively separable preferences V from the environment. The utility function is then similar to the Dixit-Stiglitz function representing "love-of-variety" preferences:

$$
\bigcup=\sum_{1}^{n} c_{i}^{\theta}+\sum_{n+1}^{n+n^{*}} \tilde{c}_{j}^{\theta}+V(E), \theta<1
$$

Production $\mathrm{x}_{\mathrm{i}}$ of home products has labour requirements $1_{\mathrm{i}}$ with:

$$
l_{i}=\alpha+\beta x_{i} \quad i=1, \ldots, n
$$

The distance to home markets can be measured as the man hours per lorry trip (for simplicity we do not model the capital embodied in cars, trains etc. explicitly here) at a certain speed; to home consumers it is $\mathrm{h}$ and to the national border it is $\mathrm{f}$. We assume that transport is taken over by a foreign partner at the border while home transporters carry imports with them on their way back home. A person per truck drives the distance $f$ to a foreign country with exported goods, then f-h back to home markets with imported goods and then the distance 
$\mathrm{h}$ to the place of production with an empty car (or takes waste back to the producers) ${ }^{2}$. A special case is when consumers live near production making $h=0$. Given that each trip by a lorry requires one driver, and one truck with a certain capacity, the number of international transports $\mathrm{t}$ is:

$$
n\left(x_{i}-c_{i}\right) / K=t
$$

where $\mathrm{x}_{\mathrm{i}}-\mathrm{c}_{\mathrm{i}}$ is the export of variant $\mathrm{i}$ and $\mathrm{K}$ is the capacity of one truck, and the labour demand required is t $\bullet$. For a transport to home markets the number of national transports $\mathrm{u}$ is:

$$
n c_{i} / K=u
$$

and the corresponding labour demand $\mathrm{u} \bullet \mathrm{h} .{ }^{3}$ Moreover, transporters need labour hours for (un-)loading cars, d, per unit produced. Of course, riding back with imported goods or with an empty lorry is part of the costs and therefore $\mathrm{tf}+\mathrm{uh}$ is multiplied by factor 2. An exceptional case may be when $\mathrm{h}>\mathrm{f}$ if, e.g., a Dutch farmer from some region in the Netherlands has lower distance to German markets than German farmers from far distanced regions have to the same German markets. However, we will only consider here symmetric cases when $\mathrm{f} \geq \mathrm{h}$.

The environment can be thought of as having some natural level $E$ that is polluted proportional to transport hours with pollution coefficient v:

$$
E=E-v 2(t f+u h)
$$

Labour market equilibrium requires that labour demand for output production, $\mathrm{nl}_{\mathrm{i}}$, for transport $2(\mathrm{tf}+\mathrm{uh})$ and loading, $\mathrm{ndx}_{\mathrm{i}}$, equals labour supply L:

${ }^{2}$ Alternatively one could assume that households transport from the firm to their home themselves, $2 \mathrm{~h}$, and imported goods are transported by the transport sector to the location of the firm, $2 \mathrm{~g}$, and from the firm to the households by the latter, $2 \mathrm{~h}$ again. Defining $\mathrm{f}=\mathrm{g}+\mathrm{h}$ implies the same modelling as done below.

${ }^{3}$ We ignore integer problems in the number of transports in (3) and (4). 


$$
n l_{i}+2 t f+2 u h+n d x_{i}-L=0
$$

For the resulting hours of pollution the transport firm pays a tax or a price, s, for pollution rights owned by the households of, in sum

$$
s 2(t f+u h)
$$

to households. Given (5) households thus receive a payment of

$$
s 2(t f+u h)=s(\bar{E}-E) / v
$$

\section{The decisions of the households and the producers}

The Lagrange function for the problem of households - with $\mathrm{p}_{\mathrm{i}}$ and $\tilde{p}_{j}$ representing prices of home and foreign goods respectively and $\mathrm{w}$ the wage rate - is:

$$
\underset{c_{i} \tilde{c}_{j}, \lambda, E}{\operatorname{aax}} U=\sum_{i}^{n} c_{i}^{\theta}+\sum_{n+1}^{n+n^{*}} \tilde{c}_{j}^{\theta}+V(E)+\lambda\left\{w L-\sum_{1}^{n} p_{i} c_{i}-\sum_{n+1}^{n+n^{*}} \tilde{p}_{j} \tilde{c}_{j}+s(E-E) / v\right\}
$$

The first-order conditions for the problem of the household are:

$$
\begin{gathered}
\delta U / \delta c_{i}=\theta c_{i}^{\theta-1}-\lambda p_{i}=0 \quad i=1, \ldots ., n \\
\delta U / \delta \tilde{c}_{j}=\theta \tilde{c}_{j}^{\theta-1}-\lambda \tilde{p}_{j}=0 \quad j=n+1, \ldots, n+n^{*} \\
\delta U / \delta \lambda=w L-\sum_{1}^{n} p_{i} c_{i}-\sum_{n+1}^{n+n} \tilde{p}_{j} \tilde{c}_{j}+s(\bar{E}-E) / v=0 \\
\delta U / \delta E=V^{\prime}-\lambda s / v \leq 0 \quad(\delta U / \delta E) \cdot E=0
\end{gathered}
$$

(10) delivers the desired level of environmental quality, E. If the desired E equals the actual one, the corresponding s will be called equilibrium tax or equilibrium price for pollution 
rights. The inequality results from the possibility that households may want to sell all pollution rights E. Whether or not this will be the case will depend on the specification of the utility function $\mathrm{V}$. We do not consider the other corner solution $\mathrm{E}=E$ because no pollution implies no transport and therefore zero consumption which cannot be an equilibrium situation. From (7) and (8), we find the equality of the marginal rate of substitution and relative prices:

$$
c_{i}^{\theta-1} / \tilde{c}_{j}^{\theta-1}=p_{i} / \tilde{p}_{j}
$$

and therefore:

$$
\tilde{p}_{j} c_{i}^{\theta-1} / \tilde{c}_{j}^{\theta-1}=p_{i}
$$

The computation of the price elasticity of demand for a large number of goods can be approximated by

$$
\delta p_{i} / \delta c_{i}\left(c_{i} / p_{i}\right)=\theta-1
$$

Within the simple model assumed here, producer prices, the terms in square brackets in the profit function below, are equal to consumer prices, $p$, net of transportation costs ${ }^{4}$. If external costs are $20 \%$ of transport costs or revenues, the Pigovian value of $\mathrm{s}$ is $\mathrm{s}=0.2 \mathrm{w}$ because transport costs consist only of wages in our simple model. The profit function of the monopolist is:

$$
\begin{gathered}
\pi_{i}=\left[p_{i}\left(c_{i}\right)-d w-(w+s) 2 h / K\right] c_{i}+\left[\tilde{p}_{j}\left(\tilde{c}_{j}\right)-d w-(w+s) 2 f / K\right]\left(x_{i}-c_{i}\right) \\
-\left\{w \alpha+w \beta\left(c_{i}+x_{i}-c_{i}\right)\right\}
\end{gathered}
$$

where $\mathrm{x}_{\mathrm{i}}-\mathrm{c}_{\mathrm{i}}=\tilde{c}_{j} \quad$ because of the assumption that countries are identical and that goods enter the utility functions symmetrically.

Maximizing the profit function with respect to $\mathrm{c}_{\mathrm{i}}$ and $\tilde{c}_{j}$ yields:

${ }^{4}$ The relationship between the monopolist and the transporter is modelled in appendix A, which is available upon request. 


$$
\begin{gathered}
\delta \pi / \delta c_{i}=p_{i}^{\prime} c_{i}+\left[p_{i}\left(c_{i}\right)-d w-(w+s) 2 h / K\right]-w \beta=0 \\
\delta \pi / \delta \tilde{c}_{j}=\tilde{p}_{j}^{\prime} \tilde{c}_{j}+\left[\tilde{p}_{j}\left(\tilde{c}_{j}\right)-d w-(w+s) 2 f / K\right]-w \beta=0
\end{gathered}
$$

\section{Solution of the model}

Using the fact that the price elasticity is $\theta-1$ and setting $\mathrm{w}=1$ the previous equations can be solved and yield:

$$
\begin{aligned}
& p_{i}=[\beta+d+(1+s) 2 h / K] / \theta \equiv \eta / \theta \\
& \tilde{p}_{j}=[\beta+d+(1+s) 2 f / K] / \theta \equiv \varphi / \theta
\end{aligned}
$$

From these expressions for prices we find proposition 1 .

PROPOSITION 1: Technical progress in variable labour inputs, $d \beta$, in (un-) loading, $d d<$ 0 , in capacity, $d K>0$, and in speed of driving, dh, $d f<0$, all considered at constant pollution $v$ per hour, reduces the prices of home and foreign goods and therefore increases real wages.

As the terms in square brackets in the equations above differ only in the distances $h$ and $\mathrm{f}$, we henceforth use $\eta$ and $\varphi$ to abbreviate them. The result for $\mathrm{p}_{\mathrm{i}}$ differs from that in Krugman (1983) because we have introduced transport costs for national trade. In our model the price ratio contains three cost terms whereas under Krugman's iceberg costs assumption, it equals the share of not melting away during transport. The difference between the two price equations mirrors the difference between $h$ and $f$. Another essential result is stated in proposition 2.

PROPOSITION 2: Payments for the environment drive prices up and real wages down. As a consequence the monopolistic inefficiency, defined as the deviation of marginal cost $(\beta)$, plus transport costs from prices, increases.

As has been pointed out by Buchanan (1969), who derived a similar result in a partial equilibrium model, this has to be taken into account when looking for an optimal subsidy as we do below in section 8 . However, as transport costs are crucial here we find the following 
result;

PROPOSITION 3: Prices of imported and exported goods are more strongly affected by environmental taxes than by prices of domestic goods because international transport differences are larger than national ones for $f>h$.

Therefore the relative price of goods produced and consumed at home and traded goods will decrease: $\delta(\eta / \varphi) / \delta s<0$. This effect on relative prices induced by s will of course vanish if $\mathrm{f}=\mathrm{h}$, a case discussed below. Setting $\mathrm{w}=1$ and using (11) one can solve for relative quantities (see appendix B, 1.)

$$
\tilde{c}_{j} / c_{i}=(\eta / \varphi)^{1 /(1-\theta)}
$$

The most important effect of environmental taxes or prices follows from this equation and is summarized in the following crucial proposition;

PROPOSITION 4: Because internationally traded goods are affected more strongly than nationally traded goods, $\delta(\eta / \varphi) / \delta s<0$, an increase in environmental tax/price leads to the substitution of internationally traded goods $\tilde{c}_{j}$ by domestically traded goods $c_{i}$.

As imported and exported goods are transported along ways of identical length, taxes on transport do not influence the terms of trade as, by assumption, both countries impose the same tax rate. By contrast, in models with pollution from consumption or production they do effect the terms of trade (see Siebert, 1979, and Krutilla, 1991). Consequently, our model emphasizes the substitution between domestic and international trade instead of terms of trade effects.

As discussed above, technical progress in transport may decrease $\mathrm{h}$ and $\mathrm{f}$ and increase K. This leads to the following proposition;

PROPOSITION 5: Decreasing $h(f)$ shifts consumption to domestic (foreign) goods. Increasing $K$ has a stronger effect on the prices of foreign goods and shifts consumption to them because $f$ is larger than $h$.

Thus, part of the environmental gains from increasing $\mathrm{K}$ are lost through substitution.

The zero-profit condition requires: 


$$
\left[p_{i}-d w-(w+s) 2 h / K\right] c_{i}+\left[\tilde{p}_{j}-d w-(w+s) 2 f / K\right] \tilde{c}_{j}-\left\{w \alpha+w \beta\left(c_{i}+\tilde{c}_{j}\right)\right\}=0
$$

The last two equations could be solved for $\mathrm{c}_{\mathrm{i}}$ and $\tilde{c}_{j}$. Replacing $\mathrm{p}_{\mathrm{i}}, \mathrm{p}_{\mathrm{j}}$ and $\mathrm{c}_{\mathrm{j}}$ in the zero profit equation and using the abbreviations mentioned above yields (see appendix B, 2.):

$$
\begin{gathered}
c_{i}^{f}=\frac{[\alpha \theta /(1-\theta)] / \varphi}{\eta / \varphi+(\eta / \varphi)^{-1 /(\theta-1)}} \\
\tilde{c}_{j}^{f}=\frac{\left[\frac{\alpha \theta}{1-\theta} / \varphi\right](\eta / \varphi)^{-1 /(\theta-1)}}{\eta / \varphi+(\eta / \varphi)^{-1 /(\theta-1)}}
\end{gathered}
$$

The upper index f stands for "free trade". The first term represents domestic consumption of domestically produced goods. The second terms represents export quantities which is equal to the amount of domestic consumption of foreign goods under the assumption of two identical countries. For $\mathrm{f}=\mathrm{h}$, prices of traded and domestic goods are identical and the increase of $\varphi$ through an increase of s will reduce the consumption of both goods by the same amount. As $\mathrm{f}>\mathrm{h}$ induces a substitution of $\tilde{c}_{j}$ for $\mathrm{c}_{\mathrm{i}}$, it is clear that $\delta \tilde{c}_{j} / \delta s<0$ whereas the substitution effect may prevent $c_{i}$ from falling if $s$ increases. With these solutions for prices and quantities we can now go back to equation (6) and solve for n, the number of domestically produced varieties. Insertion of (2) and the definitions of $t, u$ and $x_{i}$ into (6) after collecting c-terms and insertion of the free trade solutions for the c-terms yields (see appendix B, 3.):

$$
\begin{gathered}
n^{f}=\left[c_{i}(\beta+2 h / K+d)+\alpha+\tilde{c}_{j}(\beta+2 f / K+d)\right]^{-1} L= \\
{\left[\frac{\{[\alpha \theta /(1-\theta)] / \varphi\} \cdot\left\{(\beta+2 h / K+d)+(\eta / \varphi)^{-1 /(\theta-1)}(\beta+2 f / K+d)\right)}{\eta / \varphi+(\eta / \varphi)^{-1 /(\theta-1)}}+\alpha\right]^{-1} L}
\end{gathered}
$$

As the effect of the c-terms on $\mathrm{n}^{\mathrm{f}}$ is negative, the effect of $\mathrm{s}$ on $\mathrm{n}^{\mathrm{f}}$, is: 


$$
\delta n^{f} / \delta s=\left(\delta n / \delta c_{i}\right)\left(\delta c_{i} / \delta s\right)+\left(\delta n / \delta \tilde{c}_{j}\right)\left(\delta \tilde{c}_{j} / \delta s\right)>0 \quad \text { if } \quad \delta c_{i} / \delta s<0
$$

where the latter condition is fulfilled if $\mathrm{f}-\mathrm{h}$ is sufficiently small, as discussed above. Whereas in comparative advantage models the export structure may be reversed if exporters are heavily taxed by one country only (see Pethig, 1976 and Siebert 1977, 1979 on the theory and Grossman/Krueger 1991 on the empirics) this, of course, cannot be the case in a symmetric model whereby the pollution of transport is taxed by both countries. Instead we get the following proposition;

PROPOSITION 6: Both countries will produce a higher number of varieties, at least if national and international transport differences are sufficiently small. Bringing the environmental costs correctly into the cost calculations through taxes and transferring the tax revenues to households increases variety and decreases quantity.

This is achieved through the revenues from transport and pollution due to taxation. For $\mathrm{f}=\mathrm{h}$ the reduction in pollution is ${ }^{5}$ :

$$
\delta\left\{\left[v n\left(c_{i} h+\tilde{c}_{j} f\right) / K\right]\right\} / \delta s=\frac{4 f^{2} L \theta v(\theta-1)}{\{\beta k+d k-2 f[s(\theta-1)-1]\}^{2}}<0
$$

The following proposition follows from this inequality;

PROPOSITION 7: The increase in the number of varieties, induced by a higher tax rate, is smaller than the change in the quantities $c_{i}, \tilde{c}_{j}$ because new varieties require fixed labour inputs $\alpha$. Therefore the induced substitution of quantity for variety and of international for domestic transport reduce pollution.

Using the definitions of $\varphi$ and $\eta$ one can now show ${ }^{6}$ that without environmental policy, $\mathrm{s}=0$ :

$$
n^{f}=(1-\theta) L / \alpha
$$

Without environmental policy, $\mathrm{s}=0$, transport costs have no influence on the number of

${ }^{5}$ This result can be obtained by differentiation of the left-hand side with respect to $\mathrm{n}, \mathrm{c}_{\mathrm{i}}$, $\mathrm{c}^{*}$, and differentiating them with respect to the environmental tax/prices according to the parts of the solution derived above.

${ }^{6}$ Without environmental policy we have $\eta=\beta+2 \mathrm{~h} / \mathrm{K}+\mathrm{d}$, and $\varphi=\beta+2 \mathrm{f} / \mathrm{K}+\mathrm{d}$. 
varieties. The corresponding solution for $\mathrm{n}^{*}$ would be determined in the foreign countries' symmetric model. With the solution for n one can go back to (5) and solve for $\bar{E}-\mathrm{E}$, the environmental costs, using (3) and (4) and the solutions for consumption of domestic and foreign goods. Before doing that we compute the solution of the model for autarky which we will subsequently need to calculate the gains from trade.

\section{The solution for autarky}

As $\mathrm{n}^{*}$ is given, free trade could only be identical to autarky if $\tilde{c}_{j}$ would go be zero in the utility function. This in turn can only be the case if $\varphi$ goes to infinity which would require to have infinitely high prices $\tilde{p}_{j}$. Thus, unlike comparative advantage models, autarky cannot be thought of as a special case of trade where the terms of trade equal autarky prices. In autarky we have $\mathrm{c}_{\mathrm{i}}=\mathrm{x}_{\mathrm{i}}, 0=\mathrm{n}^{*}=\mathrm{t}=\tilde{c}_{j}$ and $\tilde{p}_{j}$ does not exist. The zero profit condition solved for $\mathrm{c}_{\mathrm{i}}$ yields (see appendix $\mathrm{B}, 4$. ):

$$
c_{i}^{a}=\alpha \theta /[\eta(1-\theta)]
$$

The upper index 'a' stands for 'autarky'. From the definition of $\eta$ it is clear that the following proposition can be derived.

PROPOSITION 8: Environmental payments reduce the quantity consumed of each variety whereas technical progress in transport, $d h<0$, and in capacity $d K>0$, increase it.

Modifying (6), solving for $\mathrm{n}$ and inserting the solution of $\mathrm{c}_{\mathrm{i}}$ yields (see appendix B, 5.)

$$
n^{a}=L(1-\theta)\left\{\frac{[\beta+d+(1+s) 2 h / K]}{[\beta+d+(1+s) 2 h / K]-\theta s 2 h / K}\right\} / \alpha
$$

If there were no environmental payments $(s=0)$ the solution for the number of varieties in autarky would be that of the Krugman model without transport costs. Differentiating $\mathrm{n}^{\mathrm{a}}$ with 
respect to the domestic transport distance, $\mathrm{h}$, and the environmental payment, s, yields the following proposition.

PROPOSITION 9: (a) For any environmental payment $s>0$, an increase in national transport costs, $d h>0$, increases the number of varieties available under autarky. (b) Environmental payments increase the autarkic number of firms because household income increases proportionally to the environment being taxed or "rented out" to the transport firm.

This holds because the rebatement of tax revenues and the decreased quantity consumed of each variety compensates households for the loss in environmental quality associated with each unit of emission rights bought by the transport firm.

\section{Gains from free trade reconsidered}

To consider the conventional gains from trade net of the utility losses from pollution we consider the difference between utility levels under free trade and under autarky using (1) where we fill in the elements of the solution to the model:

$$
G \equiv U^{f}-U^{a}=n^{f}\left(c_{i}^{f}\right)^{\theta}+\left(n^{*}\right)^{f}\left(\tilde{c}_{j}^{f}\right)^{\theta}+V\left(E^{f}\right)-\left[n^{a}\left(c_{i}^{a}\right)^{\theta}+\left(n^{*}\right)^{a}\left(\tilde{c}_{j}^{a}\right)^{\theta}+V\left(E^{a}\right)\right]
$$

Due to the symmetry assumption of the model we have $\mathrm{n}^{\mathrm{f}}=\mathrm{n}^{* \mathrm{f}}$. Using $\mathrm{n}^{* \mathrm{a}}=\tilde{c}_{j}^{a}=0$ and (3)-(5) the gains from trade can be written as:

$$
\begin{gathered}
G=U^{f}-U^{a}= \\
n^{f}\left[\left(c_{i}^{f}\right)^{\theta}+\left(\tilde{c}_{j}^{f}\right)^{\theta}\right]-n^{a}\left(c_{i}^{a}\right)^{\theta}+V\left[\bar{E}-2 v n^{f}\left(\tilde{c}_{j}^{f} f+c_{i}^{f} h\right) / K\right]-V\left[\bar{E}-2 v n^{a} c_{i}^{a} h / K\right]
\end{gathered}
$$

Considering the case of no environmental payments, $s=0$, we have $n^{\mathrm{f}}=\mathrm{n}^{\mathrm{a}}$, henceforth abbreviated as $\mathrm{n}$ and for $\mathrm{V}(\mathrm{E})=\mathrm{E}$ we find:

$$
G=U^{f}-U^{a}=n\left[\left(c_{i}^{f}\right)^{\theta}+\left(\tilde{c}_{j}^{f}\right)^{\theta}-\left(c_{i}^{a}\right)^{\theta}\right]-2 v n\left(\tilde{c}_{j}^{f} f+c_{i}^{f} h-c_{i}^{a} h\right) / K
$$

The first term contains the conventional gains from trade for the model with transport costs and no environmental policy and the second the expected losses from the increased pollution due to increased transport costs. Insertion of the values for $\mathrm{n}$ and the c-terms yields after some manipulation (see appendix B, 6.): 


$$
\begin{gathered}
G=L \cdot(1-\theta) \alpha^{-1} \cdot \\
\left\{\left(\frac{\alpha \theta / \varphi}{1-\theta}\right)^{\theta} \cdot \frac{\left[1+(\eta / \varphi)^{\theta /(1-\theta)}\right]-\left[1+\left(\frac{\eta}{\varphi}\right)^{\frac{\theta}{1-\theta}}\right]^{\theta}}{\left[\eta / \varphi+(\eta / \varphi)^{1 /(1-\theta)}\right]^{\theta}}\right. \\
-2 v\left\{\frac{\alpha \theta / \varphi}{1-\theta} \cdot \frac{\left.(\eta / \varphi)^{-1 /(\theta-1)} f-h\left(\frac{\eta}{\varphi}\right)^{\frac{\theta}{1-\theta}} / K\right\}}{\eta / \varphi+(\eta / \varphi)^{-1 /(\theta-1)}}\right.
\end{gathered}
$$

The first of the two terms in braces contains the conventional gains from trade which are positive as $\theta<1$ and the second the expected losses from the increased pollution due to increased transport costs which has the expected sign for $\mathrm{f}>\mathrm{h}$ and $\theta<1$. As $\mathrm{v}$ does not appear in $\eta$ and $\varphi$, it does not appear in the formula for the conventional gains from trade. This yields the following proposition;

PROPOSITION 10: If the pollution per unit of transport $v$ is sufficiently high the conventional gains from trade may be outweighed by the environmental losses from increased transport pollution.

This result had already been derived by Pethig (1976) and Siebert (1977) but in a comparative advantage model of perfect competition with pollution from output production under the additional assumption that the country in question specializes in the environment-intensive good.

Whether or not this is the case is clearly an empirical question, which we cannot address here. Grossman and Krueger (1991) cast some doubt on the empirical relevance of the shift to pollution-intensive production induced by trade. However, in this paper the result is restated here for an extension of the Krugman model based on pollution from transport, which does not depend on such a shift. Moreover, unlike Pethig's result that trade has no impact on pollution once environmental capital is fixed by an environmental standard, here trade inevitably increases pollution because international transport differences are longer than the national ones and transport is complementary to production and consumption.

Of course the assumption made in many trade policy circles, such as GATT or now WTO, that the welfare gains from free trade will "automatically" provide the means for payments to reduce pollution, are clearly subject to the same empirical evaluation because it 
ignores the pollution aspect of trade, i.e. the movement of goods through transport, itself.

\section{Equilibrium prices for pollution rights}

For s to be an equilibrium value the actual level of the environmental quality according to (5) must be equal to the desired one according to (10) which requires formally:

$$
\begin{gathered}
V^{\prime}[\bar{E}-v(t f+u h) 2]-\lambda s / v=0 \\
\text { or } \mathrm{E}=0
\end{gathered}
$$

In the latter case the household sells all emission rights because the return $\mathrm{s}$ is always higher than marginal utility of the environment: $\mathrm{s}>\mathrm{vV}^{\prime} / \lambda$.

The value of $s$ in the first case is:

$$
s=v \cdot V^{\prime}[\bar{E}-v(t f+u h) 2] / \lambda=v \cdot V^{\prime}\left\{\bar{E}-v 2 n\left[f \tilde{c}_{j}+h c_{i}\right] / K\right\} / \lambda
$$

Insertion of values for $\mathrm{n}$ and the $\mathrm{c}$ terms delivers:

$$
\begin{gathered}
s=v \cdot V^{\prime}\{\bar{E}-v 2 \cdot \\
{\left[\frac{\{[\alpha \theta /(1-\theta)] / \varphi\} \cdot\left[(\beta+2 h / K+d)+(\eta / \varphi)^{-1 /(\theta-1)}(\beta+2 f / K+d)\right]}{\eta / \varphi+(\eta / \varphi)^{-1 /(\theta-1)}}+\alpha\right]^{-1} L} \\
\left.\left[f \frac{\left[\frac{\alpha \theta}{1-\theta} / \varphi\right](\eta / \varphi)^{-1 /(\theta-1)}}{\eta / \varphi+(\eta / \varphi)^{-1 /(\theta-1)}}+h \frac{[\alpha \theta /(1-\theta)] / \varphi}{\eta / \varphi+(\eta / \varphi)^{-1 /(\theta-1)}}\right] / K\right\}= \\
v \cdot V^{\prime}\left\{E-v 2 \cdot L \frac{\{[\alpha \theta /(1-\theta)] / \varphi\}\left\{f \cdot(\eta / \varphi)^{-1 /(\theta-1)}+h\right] / K}{\{[\alpha \theta /(1-\theta)] / \varphi\}\left[(\beta+2 h / K+d)+(\eta / \varphi)^{-1 /(\theta-1)}(\beta+2 f / K+d)\right]}\right\} \\
=v \cdot V^{\prime}\left\{\bar{E}-v 2 \cdot L \frac{\left\{f \cdot(\eta / \varphi)^{-1 /(\theta-1)}+h\right\} / K}{\left[(\beta+2 h / K+d)+(\eta / \varphi)^{-1 /(\theta-1)}(\beta+2 f / K+d)\right]}\right\}
\end{gathered}
$$

The argument in $V^{\prime}$ contains the equilibrium level of environmental resources. The part subtracted from $\bar{E}$ is the equilibrium level of the environmental damage. As $\mathrm{s}$ is also contained in $\eta$ and $\varphi$ a solution of s can only be found for specifications of $V(E)$. We 
consider three cases.

Firstly, the specification $\mathrm{V}(\mathrm{E})=\mathrm{E}$ implies $\mathrm{V}^{\prime}=1$ and $\mathrm{s} \geq \mathrm{v} / \lambda$. The equilibrium price for pollution rights is $v / \lambda$ or at $s>v / \lambda>0$ the households sell all rights such that $E=0$ because $\mathrm{s}>\mathrm{vV} / \lambda$.

Secondly, the specification $V(E)=E^{\theta}$ and $V^{\prime}=\theta E^{(\theta-1)}$ is used. Here we must get the internal solution of (10'), because for $\mathrm{E}=0$ marginal utility from the environment would go to infinity. Therefore the household will always keep some rights.

Thirdly, we assume $\mathrm{V}(\mathrm{E})=\ln \mathrm{E}$ implying $\mathrm{V}^{\prime}=\mathrm{E}^{-1}$. As a result, and under the additional simplifying assumption $\mathrm{f}=\mathrm{h}$, we get a non-unique equilibrium value for the tax/subsidy:

$$
s=\frac{ \pm \sqrt{B}}{4 \bar{E} f(\theta-1)}+\frac{\beta K}{4 f(\theta-1)}+\frac{d K}{4 f(\theta-1)}+\frac{v(\theta-1-L \theta)}{E 2(\theta-1)}+\frac{1}{2(\theta-1)}
$$

In the first term SQRT B is an abbreviation for the square root of some lengthy expression B. Only the second but last term is positive for $\mathrm{L}>1$. If $\mathrm{f}, \mathrm{v}$ and $\mathrm{L}$ are sufficiently large then the sum of the last four terms is positive. Together with the negative SQRT B the equilibrium tax is positive for high transport costs $\mathrm{f}$, strong pollution $\mathrm{v}$ and a large market expressed through high $\mathrm{L}$ if people value the environment sufficiently higher as its quality decreases. A negative solution can be ruled out because again marginal utility would be at infinity which induces households to keep some rights.

\section{Optimal taxes and subsidies}

The consideration of optimal taxes or subsidies is interesting for two reasons. For one, because of the fact that equilibrium and optimal solutions to the environmental externality will not be identical in this model because there is also a monopolistic inefficiency and because the endogenous number of products exerts an externality on households. The literature considering the deviation of optimal from equilibrium taxes/subsidies is of the partial equilibrium type following Buchanan (1969). Two, after having shown in the previous section that the existence of equilibrium taxes/subsidies may lead to a complete selling of environmental rights, it is interesting to see which results follow from tax policy analysis. Although there are three imperfections (the number of varieties is given to the households but endogenous to the model, monopolistic prices deviate from marginal costs and there is no 
market for pollution rights) we use only one instrument, pollution taxes. The motivation is that under zero profits governments will hardly interfere with monopoly and the variety externality will supposedly be ignored as well.

Again we consider the three specifications given above. The solutions for the number of varieties, domestic and imported consumption goods, are inserted into the utility function, which is maximized with respect to the environmental tax/subsidy, s. We report the results only.

For $\mathrm{V}(\mathrm{E})=\mathrm{E}$ and $\mathrm{V}^{\prime}=1$ we find the optimal tax/subsidy as the implicit solution of:

$$
\begin{gathered}
{[f h s(2 \theta-2)-\beta K(f-h \theta)+d K(f-h \theta)+f h(2 \theta-2)]} \\
{\left[\frac{2 h s+\beta K+d K+2 h}{2 f s+\beta K+d K+2 f}\right]^{1 /(\theta-1)}+f^{2} s(2 \theta-2)+f(\theta-1)(\beta K+d K+2 f)=0}
\end{gathered}
$$

Suppose $\mathrm{s}>0$, then $\mathrm{f} \geq \mathrm{h}$ and $\theta<1$ lead to a contradiction because all terms on the left side of the equation are negative. Therefore we get the following proposition;

PROPOSITION 11: Under a linear utility function the tax $s$ must be negative whereas it was positive in the corresponding market equilibrium. The reason is that a positive tax would decrease pollution and is likely to increase the number of varieties and therefore it also increases the monopolistic inefficiency of prices deviating from marginal costs $\beta$. This latter inefficiency is dominating with the specification at hand.

This is a general equilibrium formulation of Buchanan's (1969) problem. Even if environmental quality would go to zero, marginal utility is not increasing because of the assumption of a linear utility function. The value of the environment is thus constant whereas the value of the foregone consumption goods under a positive tax is increasing if consumption is reduced and the monopolistic inefficiency is increased (decreased) by a positive (negative) tax.

The simplest next step is again to give the environment the same elasticity of utility as consumption, namely $\theta$. This leads to the following proposition;

PROPOSITION 12: For $V(E)=E^{\theta}$ and $V^{\prime}=\theta E^{\theta-1}$, the case where no market equilibrium existed in the previous section, we find an optimal tax/subsidy $s=0$ for the simplification $h$ $=f$. For positive taxes the increase in the monopolistic inefficiency would more than outweigh the sum of the environmental gains and the increase in utility through an increase in the number of varieties. 
However, if $\mathrm{f}>\mathrm{h}$, an increase in environmental taxes, $\mathrm{ds}>0$, is likely to shift transport services and demand from international to national transport. Therefore an optimal subsidy may be positive for $\mathrm{f}>\mathrm{h}$.

The result of a tax at level zero for $\mathrm{f}=\mathrm{h}$ may be viewed as counterintuitive in view of the urgency of some environmental problems. Therefore we increase the marginal utility of low values of environmental quality even further, assuming $V(E)=\ln E$ and $V^{\prime}=E^{-1}$. As a condition for positivity of the optimal tax for $f=h$ we now get:

$$
\left\{\bar{E} f s^{2}\left(4 \theta^{2}-8 \theta+4\right)-2 s(\theta-1)[\beta \bar{E} K+d \bar{E} K+2 f(\bar{E}-L \theta v)]\right\}>0
$$

To derive a condition for $\mathrm{s}>0$ we divide this expression by $\mathrm{s} \underset{(<)}{>} 0$, which yields the condition:

$$
s \underset{(<)}{>} \frac{2(\theta-1)\left[\frac{\beta E K+d E K}{f}+2(E-L \theta v)\right]}{\bar{E} 4\left(\theta^{2}-2 \theta+1\right)}
$$

As the denominator is positive we find the following proposition;

PROPOSITION 13: For sufficiently high values of the pollution coefficient $v$ and the size of the market $L$, the right side is positive and therefore a tax $(s)$ will have to be positive as it was under similar conditions in the market equilibrium considered in the previous section. A growing economy which is captured through growth in L here requires a positive tax after some time and growing taxation once the tax is positive ${ }^{7}$

Generally speaking, positive optimal taxes require a utility function that is steeper in the environmental part than in that of the quantities. Otherwise optimal taxes may be negative or zero, because the monopolistic inefficiency is dominating. Unlike Buchanan (1969), we derived the exact assumptions that are underlying these results in a general equilibrium framework.

${ }^{7}$ Sinclair (1992) argues that this may be an incentive to increase resource extraction in the short run where producer prices for carbon fuel are high. We assume here that resource extraction policy will not counteract international agreements to increase taxes and reduce pollution. 


\section{Conclusion}

Since we have put the results in the form of propositions we do not summarize them again here.

The policy results of our model depend strongly on peoples' preferences for environmental quality, which may be quite different among individuals, and on the severity of pollution itself, which under imperfect information is highly subjective.

In our view the most interesting case in the model is the one where taxes on pollution are positive because the underlying preferences seem to mirror the urgency of the environmental problem more adequately. However, the main implication of our analysis, is the relatively straightforward illustration that under 'realistic' assumptions, the market solution is not only necessarily non-optimal.

As illustrated in section 8 , growing taxes on pollution seem to be a more reliable general strategy towards optimal policy than any attempt to install "new pollution markets". The latter will in the best case lead to a market equilibrium which will yield all the "Pigovian" prices that have correctly been characterized by Buchanan as suboptimal.

This result is of course against economists' intuition that markets do economize and allocate better than governments. This intuition has, however, been formed under the impression of traditional markets for which property rights had not to be established through the government as is the case with pollution rights. Government action to distribute pollution rights and to organize a market involves risks of both a market failure as well as government failure.

\section{References}

Barnett, A. H. (1980), The Pigouvian Tax Rule under Monopoly, in: American Economic Review, 1037-1041.

Buchanan, James M. (1969), External Diseconomies, Corrective Taxation and Market Structure, in: American Economic Review, 174-177.

Conrad, K. (1993), Taxes and Subsidies for Pollution-Intensive Industries as Trade Policy, in: Journal of Environmental Economics and Management 25, 121-135.

Dogs, Ernst, Gunther Ellwanger and Holger Platz (1991), Externe Kosten des Verkehrs, in: Die Bundesbahn 1, p.39-45. 
Grossman, Gene M. and Alan B. Krueger (1991), Environmental Impacts of a North American Free Trade Agreement, NBER Working Paper No. 3914, November.

Judd, K. (1985), On the Performance of Patents, in: Econometrica, Vol. 53, No. 3, May, 567585 .

Katz, Lawrence F. and Lawrence H. Summers (1989), Industry Rents: Evidence and Implications, in: Brookings Papers on Economic Activity: Microeconomics, 209-290.

Krugman, P.R. (1979), Increasing Returns, Monopolistic Competition, and International Trade, Journal of International Economics 9, 4 (November), 469-479.

Krugman, P.R. (1981), Intraindustry Specialization and the Gains from Trade, in: Journal of Political Economy 89, 5, 959-974.

Krugman, P. R. (1983), The 'New Theories' of International Trade and the Multinational Enterprise, in: C.P. Kindleberger and D.B. Audretsch, The Multinational Corporation in the 1980s, MIT Press, Cambridge, Massachusetts, London, England.

Krutilla, Kerry (1991), Environmental Regulation in an Open Economy, in: Journal of Environmental Economics and Management 20, 127-142.

Lee, Dwight R. (1975), Efficiency of Pollution Taxation and Market Structure, in: Journal of Environmental Economics and Management 2, 69-75.

Maks, J.A.H. (1994), Competition Policy and Imperfect Information, The Netherlands 19871992, METEOR Research Memorandum RM/0/94-034, 13p.

Markusen, James R., Edward R. Morey and Nancy Olewiler (1993),

Environmental Policy when market structure and plant locations are endogenous, in: Journal of Environmental Economics and Management 24, 69-86.

McGuire, M.C. (1982), Regulation, Factor Rewards, and International Trade, in: Journal of Public Economics 17, 335-354.

Merrifield, John D. (1988), The Impact of Selected Abatement Strategies on Transnational Pollution, the Terms of Trade, and Factor Rewards: A General Equilibrium Approach, in: Journal of Environmental Economics and Management 15, 259-284.

Morrison, C.J. (1989), Unravelling the productivity growth slowdown in the U.S., Canada, and Japan, NBER Working Paper 2993.

Morrison, C.J. (1990), Market Power, Economic Profitability and Productivity Growth Measurement: An Integrated Structural Approached. NBER Working Paper 3355, May.

Morrison, C.J. (1992), Unravelling the Productivity Growth Slowdown in the United States, Canada and Japan: The Effects of Subequilibrium, Scale Economies and Markups, in: The 
Review of Economics and Statistics, Vol.LXXIV, August, Number 3, 381-93.

Pethig, Rüdiger (1976), Pollution, Welfare, and Environmental Policy in the Theory of Comparative Advantage, in: Journal of Environmental Economics and Management 2, 160-169.

Siebert, Horst (1977), Environmental Quality and the Gains from Trade, in: Kyklos, 30, 657-673.

Siebert, Horst (1979), Environmental Policy in the Two-Country-Case, in: Zeitschrift für Nationalökonomie, (Journal of Economics), Vol. 39, 259-274.

Sinclair, P. (1992), High does nothing and rising is worse: carbon taxes should keep declining to cut harmful emissions, in: The Manchester School, Vol. LX No. 1, March, 41-52.

Autorenhinweis:

Luc Soete, born 1950, studied economics at the Universities of Gent, Antwerp and Sussex. Professor International Economics at the Maastricht University and Director of the Maastricht Economic Research Institute on Innovation and Technology (MERIT). Major areas of interest International Economics and the Economics of Technical Change. Address: MERIT, P.O.Box 616, NL-6200 MD Maastricht. e-mail: L.Soete@algec.unimaas.NL.

Thomas Ziesemer, born 1953, studied economics at the Universities of Kiel and Regensburg. Assistant professor international economics and associate professor microeconomics, Maastricht University. Fields of Interest: Growth theory, development, international, environmental and microeconomics, economics of technical change. Address: MERIT, P.O.Box 616, NL-6200 MD Maastricht. e-mail: T.Ziesemer@algec.unimaas.NL. 